\title{
Polymerase chain reaction (PCR) amplification of a nucleoprotein gene sequence of infectious hematopoietic necrosis virus
}

\author{
C. K. Arakawa ${ }^{1}$, R. E. Deering ${ }^{1}$, K. H. Higman ${ }^{1}$, K. H. Oshima ${ }^{1}$, P. J. O'Hara ${ }^{2}$, \\ J. R. Winton ${ }^{1}$ \\ ${ }^{1}$ U.S. Fish and Wildlife Service, National Fisheries Research Center, Bldg 204, Naval Station, Seattle, Washington 98115, USA \\ ${ }^{2}$ ZymoGenetics Inc., 4225 Roosevelt Way NE, Seattle, Washington 98105, USA
}

\begin{abstract}
The polymerase chain reaction (PCR) was used to amplify a portion of the nucleoprotein (N) gene of infectious hematopoietic necrosis virus (IHNV). Using a published sequence for the Round Butte isolate of IHNV, a pair of PCR primers was synthesized that spanned a 252 nucleotide region of the $\mathrm{N}$ gene from residue 319 to residue 570 of the open reading frame. This region included a 30 nucleotide target sequence for a synthetic oligonucleotide probe developed for detection of IHNV $N$ gene messenger RNA. After 25 cycles of amplification of either messenger or genomic RNA, the PCR product (DNA) of the expected size was easily visible on agarose gels stained with ethidium bromide. The specificity of the amplified DNA was confirmed by Southern and dot-blot analysis using the biotinylated oligonucleotide probe. The PCR was able to amplify the $\mathrm{N}$ gene sequence of purified genomic RNA from isolates of IHNV representing 5 different electropherotypes. Using the IHNV primer set, no PCR product was obtained from viral hemorrhagic septicemia virus RNA, but 2 higher molecular weight products were synthesized from hirame rhabdovirus RNA that did not hybridize with the biotinylated probe. The PCR could be efficiently performed with all IHNV genomic RNA template concentrations tested (1 ng to $1 \mathrm{pg}$ ). The lowest level of sensitivity was not determined. The PCR was used to amplify RNA extracted from infected cell cultures and selected tissues of infected rainbow trout. The combination of PCR and nucleic acid probe promises to provide a detection method for IHNV that is rapid, highly specific, and sensitive.
\end{abstract}

\section{INTRODUCTION}

Infectious hematopoietic necrosis virus (IHNV) is an important fish rhabdovirus causing severe epizootics among stocks of sockeye salmon (Oncorhynchus nerka), chinook salmon (O. tshawytscha), and rainbow and steelhead trout (O. mykiss) in western North America (Wolf 1988). The virus has been transmitted to Japan, Taiwan, France, and Italy by the shipment of infected fish or eggs (Sano 1976, Chen et al. 1983, Baudin-Laurencin 1987, Bovo et al. 1987). Because infectious hematopoietic necrosis is an untreatable disease, avoidance of the virus is the only available control measure (Pilcher \& Fryer 1980). Typically, the detection of IHNV relies on tissue culture methods for viral isolation and confirmatory serum neutralization tests (Amos 1985).

Because these cell culture techniques are timeconsuming and expensive, serological tests for identi- fication of IHNV have been developed (Dixon \& Hill 1984, McAllister \& Schill 1986, Way \& Dixon 1988). Although rapid, these direct methods lack the ability to detect low levels of IHNV antigen present in some samples.

During the last few years, a powerful technique for amplification of nucleic acids, the polymerase chain reaction (PCR), has become available (Saiki et al. 1985). This method results in an exponential increase in DNA from repeated cycles of synthesis in which a high temperature DNA polymerase is used together with 2 primers that span the sequence selected for amplification (Saiki et al. 1988). When performed optimally, this method enables the synthesis of easily detectable amounts of DNA from only a few copies (theoretically one) of the target nucleic acid sequence (Erlich 1989, Guatelli et al. 1989). The technique has proven effective for use on viral nucleic acids purified from cell culture or extracted directly from clinical 
specimens (Ou et al. 1988, Hsia et al. 1989, Larzul et al 1989, Melchers et al. 1989).

To apply this technology to the detection of a fish virus, we used PCR to amplify a selected sequence of the nucleoprotein $(\mathrm{N})$ gene of IHNV The method was applicable to both messenger and genomic RNA and provided large amounts of DNA from all isolates of IHNV tested. In addition, we have developed a synthetic oligonucleotide probe for detection of IHNV mRNA from infected fish cell lines (manuscript in preparation). The use of PCR, coupled with a non-radioactive oligonucleotide probe, promises to provide a safe and rapid test for IHNV that is highly specific and exceptionally sensitive.

\section{MATERIALS AND METHODS}

Seven isolates of IHNV were used in this study (Table 1). These included an isolate from each of the different electropherotypes described by Hsu et al. (1986). For comparative purposes, 2 other fish rhabdoviruses, the hirame rhabdovirus (HRV) and viral hemorrhagic septicemia virus serotype F1 (VHSV; Wolf 1988), were included. All viruses were grown in the chinook salmon embryo (CHSE-214) cell line (Lannan et al. 1984 ) at $15^{\circ} \mathrm{C}$ for 5 to $7 \mathrm{~d}$. Each virus was harvested and purified on both discontinuous and continuous sucrose gradients, using methods similar to those of Leong et al. (1981), Genomic RNA was extracted by a modification of the method described by Kurath \& Leong (1985), in which proteinase K was substituted for pronase.

Two DNA oligonucleotide primers appropriate for PCR amplification were designed using a published sequence of the $\mathrm{N}$ gene of the Round Butte strain (RB76) of IHNV (Gilmore \& Leong 1988). These were selected primarily to produce a PCR product of a size (approximately 250 nucleotides) that could be easily amplified and identified on an agarose gel. Each primer was designed to have $\mathrm{a} \mathrm{T}_{\mathrm{m}}$ of $58^{\circ} \mathrm{C}$, to have little internal complementarity, and to hybridize to regions of the $\mathrm{N}$ gene that encoded amino acids with relatively low codon degeneracy. The first primer (5'TTCGCAGATCCCAACAACAA-3') was 20 nucleotides long and hybridized to positions 319-338 (sense orientation) in the open reading frame (ORF) of the $N$ gene, the second (5'-CTTGGTGAGCTTCTGTCCA-3') was 19 nucleotides long and hybridized to positions 570-552 of the ORF (antisense orientation). The primers thus bracketed a 252 nucleotide region of the $N$ gene that included a sequence complementary to an oligonucleotide probe used in our laboratory for identification of IHNV. This probe $\left(5^{\prime}\right.$-CTTGTTTTGGCAGTATGTGGCCATCT'TGTC-3') was 30 nucleotides in length and hybridized to a region of the $\mathrm{N}$ gene mRNA (positions 456-427 of the ORF, antisense orientation) which encoded a sequence particularly rich in amino acids with low-degeneracy codons. All oligonucleotides were synthesized on an Applied Biosystems (Foster City, CA) model 380A DNA synthesizer using established techniques.

For amplification, IHNV, HRV, or VHSV genomic RNA was first copied into copy DNA by a reverse transcriptase $(\mathrm{RT})$ reaction at $50^{\circ} \mathrm{C}$ for $20 \mathrm{~min}$. To $1 \mathrm{ng}$ IHNV (5 ng HRV or VHSV) RNA, we added $2.5 \mathrm{U}$ of avian myeloblastosis RT (BRL, Ciathersburg, MA), 100 pM of the $3^{\prime}$ and 5' primers, and $1.25 \mathrm{mM}$ of each of the 4 deoxynucleoside triphosphates in PCR buffer supplied with a commercially available kit (GeneAmp, Perkin Elmer Cetus, Norwalk, CT). The cDNA was subsequently amplified by adding $2.5 \mathrm{U}$ of Taq polymerase (Perkin Elmer Cetus) to the reaction mixtures. The mixtures were incubated for 25 cycles in an automatic thermal cycler (Coy Laboratory Products, Ann Arbor, MI) programmed for $1 \mathrm{~min}$ at $95^{\circ} \mathrm{C}, 30 \mathrm{~s}$ at $40^{\circ} \mathrm{C}$. and 2 min at $72^{\circ} \mathrm{C}$.

The amplified product was analyzed for purity and size by electrophoresis $(50 \mathrm{~V}, 4 \mathrm{~h})$ in $2 \%$ agarose gels stained with ethidium bromide. To confirm that the product contained the appropriate $\mathrm{N}$ gene sequence, both Southern and dot blots were reacted with the biotinylated oligonucleotide probe.

To compare the sensitivity of the PCR using different levels of starting template, 10 -fold dilutions of purified

Table 1 Isolates of infectious hematopoietic necrosis virus used in this study

\begin{tabular}{|c|c|c|c|}
\hline Isolate & Host & Geographic area & Type \\
\hline $\mathrm{RB}-76$ & Oncorhynchus mykiss & Deschutes River, Oregon & 1 \\
\hline LWS & O. tshawytscha & Columbia River, Washington & 2 \\
\hline SRCV & O. tshawytscha & Sacramento River, California & 3 \\
\hline Coleman. & O.tshawytscha & Sacramento River, California & 4 \\
\hline CR & O. nerka & Cedar River, Washington & 5 \\
\hline OSV & O. nerka & Willamette River, Oregon & NT \\
\hline WRAC & O. mykiss & Hagerman Valley, Idaho & NT \\
\hline
\end{tabular}


viral RNA were made from 1 ng to 1 pg concentrations. Each template concentration was incubated for 20,25 30,40 , and 50 cycles of PCR and the product assayed on agarose gels.

To test the ability of PCR to amplify viral RNA extracted from infected fish cell cultures, Chumheart (CHH-1) cells (Lannan et al. 1984) were infected with the RB-76 strain of IHNV and incubated for $24 \mathrm{~h}$. Total RNA was extracted using the RNAzol B method (Cinna Biotecx, Friendswood, TX) and amplified by 25 cycles of PCR. The resulting product was analyzed by agarose gel electrophoresis and confirmed by dot-blot assay using the biotinylated oligonucleotide probe.

To determine the ability of the PCR to amplify viral RNA extracted from tissues of infected fish, rainbow trout (approximately $25 \mathrm{~g}$ ) were artificially infected by waterborne exposure to $10^{2}, 10^{3}$ or $10^{4}$ plaque forming units (PFU) $\mathrm{ml}^{-1}$ of the Western Regional Aquaculture Consortium (WRAC) strain of IHNV. Three days postinfection, fish were sacrificed and kidney/spleen composites and leucocytes were collected for viral assay. Tissues were diluted 1:20 in Eagle's minimum essential medium (AutoPow, Flow Laboratories, McLean, $\mathrm{VA}$ ) and homogenized. Leucocytes were isolated from whole blood samples by centrifugation at $1000 \times g$ on Histopaque gradients (Sigma Laboratories, St. Louis, MI). Infectious virus in the tissue and leucocyte samples was determined by plaque assay (Batts \& Winton 1989). The RNA was extracted from $250 \mu \mathrm{l}$ of tissue homogenate or $1 \times 10^{5}$ leucocytes using RNAzol B. For PCR, $10 \mu \mathrm{l}$ of the RNA extract from tissue samples, or 25 $\mu \mathrm{l}$ for leucocyte extracts, was used as starting template for amplification.

\section{RESULTS AND DISCUSSION}

The PCR amplification of a portion of the IHNV nucleoprotein gene yielded a large amount of product of predicted molecular weight. The method was equally efficient whether messenger or genomic RNA was used as starting material. Because the purpose of this study was to use PCR to amplify the target sequence for an oligonucleotide probe that could be used for rapid detection and identification of IHNV, we chose a primer pair that flanked the probe binding site by about 100 nucleotides on either side.

For most viral diagnostic applications, the optimal sites for locating PCR primers occur within sequences that are conserved among all isolates or strains of the virus. Because rhabdoviruses have been shown to have a high degree of genetic heterogeneity (Steinhauer et al. 1989), and no sequence information is available for other strains of IHNV, the validity of our choice for primer sites was tested on an isolate from each of the 5 electropherotypes of IHNV described by Hsu et al. (1986). These electropherotypes are based on differences in molecular weight of the nucleoprotein and glycoprotein of different strains, and probably encompass the maximum genetic diversity that can be expected for isolates of IHNV.

The oligonucleotide primers directed the synthesis of a 252 base-pair (bp) segment of DNA from each of the 7 isolates of IHNV used in this study. After 25 cycles of PCR amplification, a single band of DNA of the expected molecular weight was observed after agarose gel electrophoresis and ethidium bromide staining (Fig. 1). These results suggest that the primer and probe sequences selected were conserved among the different strains of IHNV and that the reaction conditions used in this study should be appropriate for all isolates of the virus.

No PCR product was detected after 25 incubation cycles in which genomic RNA of VHSV and the IHNV primer set were used. The inability of the primers to bind to sequences within the VHSV genome and initiate polymerization suggested that the primers were relatively specific for IHNV and that the technique could be used to distinguish IHNV from VHSV infec-
Fig. 1. Agarose gel stained with ethidium bromide. The DNA products resulting from polymerase chain reaction (PCR) amplification of an $N$ gene sequence of infectious hematopoietic necrosis virus (IHNV) were analyzed by electrophoresis to determine the purity and size of amplified DNA. Lanes are: (1) 123 bp mol wt ladder; (2) Round Butte IHNV; (3) Little White Salmon IHNV; (4) Sacramento River Chinook Virus IHNV; (5) Coleman IHNV; (6) Cedar River IHNV; (7) Oregon Sockeye Virus IHNV; (8) Western Regional Aquaculture Consortium IHNV; (9) Hirame Rhabdovirus; (10) Viral Hemorrhagic Septicemia Virus; and (11) GeneAmp Kit control (500 bp product)

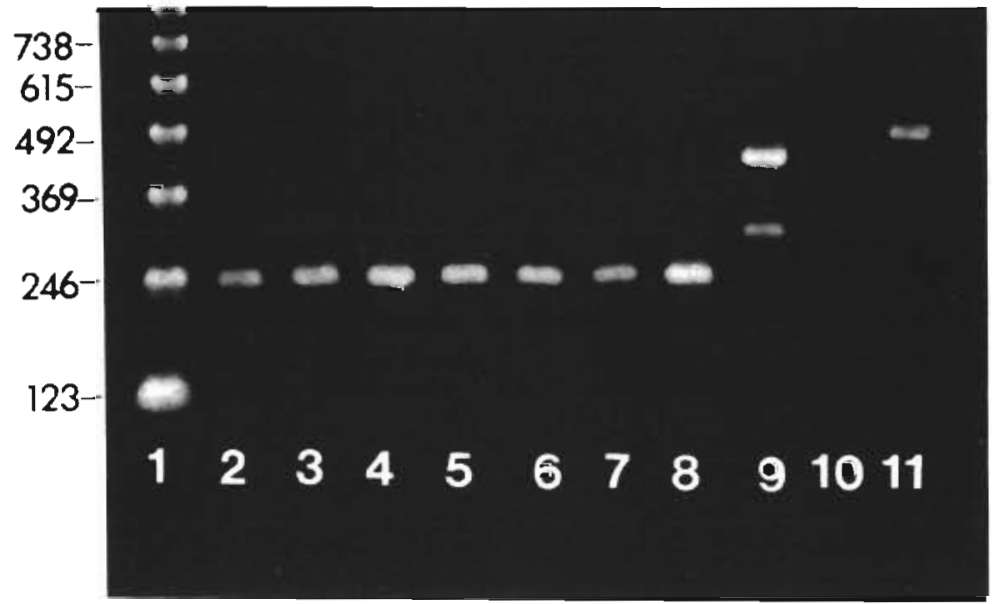


tions in fish. The data also indicated that, at least at the selected primer sequences, there was significant genetic diversity between IHNV and VHSV.

Although no PCR product was obtained from VHSV, 2 bands of about 430 and 280 bp were detected after amplification of HRV. This rhabdovirus has been found to be related to, but is not identical with, IHNV (P.E.V. Jorgensen pers. comm., T. Nishizawa unpubl. data). Because the bands were of different molecular weight, multiple sites with partial homology may have been recognized by the IHNV primers. Additional analysis of the IHNV and HRV genomes will be required before the relationship between the 2 viruses becomes clear.

To confirm the presence of the IHNV probe sequence within the 252 bp segments produced by $P C R$, we used both Southern and dot blot analyses of the amplification products. After transfer to nitrocellulose paper, the Southern and dot blots were probed using a biotinylated oligonucleotide. All of the $252 \mathrm{bp}$ PCR products from the IHNV isolates hybridized strongly with the probe by Southern (Fig. 2) or dot blot assay. Although present at a concentration too low to be seen in agarose gels stained with ethidium bromide, a band of DNA of approximately 500 bp was recognized by the probe (Fig. 2). The origin of this DNA is unknown, but it probably included background amplification products. As expected, hybridization with the probe did not occur with the VHSV PCR product nor with the high molecular weight HRV products

The PCR was able to efficiently amplify purified IHNV RNA at all starting template concentrations tested. However, 30 or more cycles of PCR were required to produce sufficient DNA to be visualized with ethidum bromide when the starting template concentration was reduced to 1 pg of RNA.
A 252 bp PCR product was detected on agarose gels after amplification of RNA extracted from infected cell cultures. Although both primers were used for the reverse transcriptase reaction, it is likely that viral messenger RNA was the primary molecule amplified due to the early stage of infection at which cultures were harvested. No cytopathic effect was observed in the cell monolayer at harvest and no product was obtained from RNA extracts of uninfected cells. The PCR product reacted strongly with the oligonucleotide probe by dotblot assay confirming that the predicted $N$ gene sequence was amplified.

While additional experiments are in progress to determine the optimal conditions for PCR amplification of IHNV from infected fish tissues and to extend the sensitivity of a PCR-based assay, our initial experiments showed IHNV detection levels by PCR approximated those of a cell culture assay. A 252 bp segment was produced from all kidney/spleen and leucocyte RNA extracts from fish challenged with $10^{4} \mathrm{PFU} \mathrm{ml}^{-1}$ IHNV. A PCR product was produced from 2 of 3 kidney/spleen extracts and the pooled leucocyte extract from fish challenged with $10^{3} \mathrm{PFU} \mathrm{ml}^{-1}$ virus. No PCR product was obtained from RNA extracted from any fish challenged with the lowest concentration of virus. Fish positive by PCR were also positive by plaque assay (except for one fish from the lowest challenge group that was positive by plaque assay but not by PCR). The PCR was able to amplify viral RNA extracted from tissues with viral titers that ranged from $4 \times 10^{2}$ to greater than $4 \times 10^{7} \mathrm{PFU} \mathrm{ml} \mathrm{m}^{-1}$ Agarose gel analysis of the extracts showed that PCR amplification of the 252 bp target sequence accurred in the presence of large amounts of nonviral RNA.

Although this study represents the use of $\mathrm{PCR}$ for the

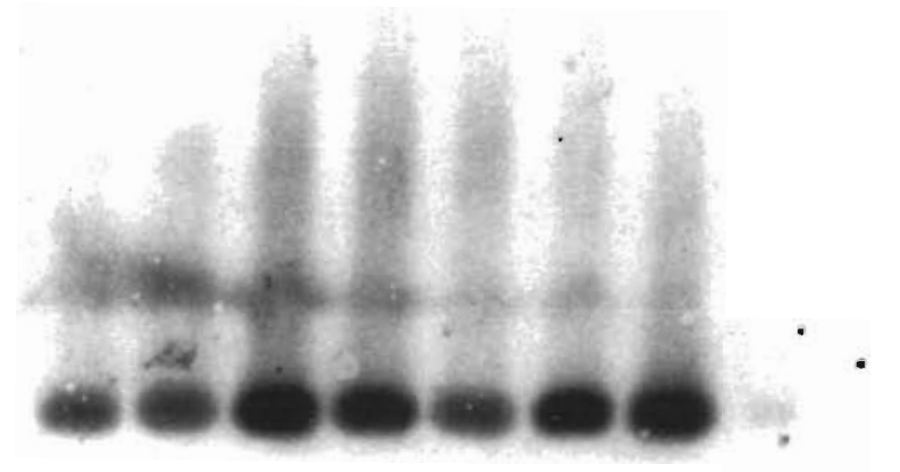

\section{$\begin{array}{lllllllllll}1 & 2 & 3 & 4 & 5 & 6 & 7 & 8 & 9 & 10 & 11\end{array}$}

Fig. 2. Southern blot of PCR products probed with a biotin-labeled oligonucleotide complementary to a 30 nucleotide sequence of the messenger RNA of the nucleoprotein gene of infectious hematopoietc necrosis virus (IHNV). See Fig. 1 for lanes 
diagnosis of a fish virus, it is likely that this powerful technology will find broad application in many aspects of fisheries science. In addition to detection and identification of fish pathogens, research on stock identification, gene expression, taxonomy, and forensics will be facilitated by this method.

Because 25 cycles of PCR can result in the amplification of the target sequence more than 30-million-fold $\left(2^{25}\right)$, the method can theoretically detect single copies of certain genes, pathogens, or other sequences of interest. The exponential increase in product provides the key to the high sensitivity of PCR for diagnostic applications, but emphasizes the importance of preventing unwanted sequences from being amplified as well (Clewley 1989). For PCR-based diagnostic kits, special care must be taken to avoid contamination with other samples.

Agarose gel electrophoresis is frequently used to verify that the selected target sequence has been amplified to produce DNA segments of expected length. The use of a nucleic acid probe to confirm the internal sequence of the PCR product provides an important double check. The large amount of DNA produced by PCR can be easily detected by enzymeconjugated probes, making radioactive labeling unnecessary and allowing the development of kits that would be appropriate for use in fish hatcheries. When coupled to a battery of nucleic acid probes, automated procedures for the rapid, highly specific, and extremely sensitive identification of fish pathogens are possible. These methods will be faster and less costly than present techniques and will be particularly valuable for detection of latent or integrated viral pathogens. Because of these substantial advantages, the combination of PCR and nucleic acid probe methods will find increasing use in fish disease diagnostics.

Acknowledgements. We thank Pete Lockhart for technical assistance with the synthesis of the primers and probes used in this study. Portions of this work were conducted with funds from the Western Regional Aquaculture Consortium under U.S. Department of Agriculture Grant No. 87-CRSR-2-3219.

\section{LITERATURE CITED}

Amos, K. H. (1985). Procedures for the detection and identification of certain fish pathogens, 3rd edn. Fish Health Section, American Fisheries Society, Corvallis, Oregon

Batts, W. N., Winton, J. R. (1989). Enhanced detection of infectious hematopoietic necrosis virus by pretreatment of cell monolayers with polyethylene glycol. J. Aquat. Animal Health: (in press)

Baudin-Laurencin, F. (1987). IHN in France. Bull. eur. Ass. Fish Pathol. 7: 104

Bovo, G., Giorgetti, G., Jorgensen, P. E. V., Olesen, N. J. (1987). Infectious hematopoietic necrosis: first detection in Italy. Bull. eur. Ass. Fish Pathol. 7: 24
Chen, S. N., Kou, G. H., Hedrick, R. P., Fryer, J. L. (1983). The occurrence of viral infections of fish in Taiwan. In: Ellis, A. E. (ed.) Fish and shellfish pathology. Academic Press, New York, p. 313-319

Clewley, J. P. (1989). The polymerase chain reaction, a review of the practical limitations for human immunodeficiency virus diagnosis, J. virol Meth. 25: $179-188$

Dixon, P. F., Hill, B. J. (1984). Rapid detection of fish rhabdoviruses by the enzyme-linked immunosorbent assay (ELISA). Aquaculture 42: 1-12

Erlich, H. A. (1989). PCR Technology, Principles and applications for DNA amplification. Stockton, New York

Gilmore, R. D., Leong, J. C. (1988). The nucleocapsid gene of infectious hematopoietic necrosis virus, a fish rhabdovirus. Virology 167: 644-648

Guatelli, J. C., Gingeras, T R., Richman, D. D. (1989). Nucleic acid amplification in vitro: Detection of sequences with low copy numbers and application to diagnosis of human immunodeficiency virus type 1 infection. Clin. microbiol. Rev. 2: 217-226

Hsia, K., Spector, D. H., Lawrie, J., Spector, S. A. (1989). Enzymatic amplification of human cytomegalovirus sequences by polymerase chain reaction. J. clin. Microbiol. 27: $1802-1809$

Hsu, Y L., Engelking, H. M., Leong, J. C. (1986). Occurrence of different types of infectious hematopoietic necrosis virus in fish. Appl. environ. Microbiol. 52: 1353-1361

Kurath, G., Leong, J. C. (1985). Characterization of infectious hematopoietic necrosis virus $m$ RNA reveals a nonvirion rhabdovirus protein. J. Virology 53: 462-468

Lannan, C. N., Winton, J. R., Fryer, J. L. (1984). Fish cell lines: establishment and characterization of nine cell lines from salmonids. In Vitro 20: 671-676

Larzul, D., Chevrier, D., Guesdon, J. A. L. (1989). A nonradioactive diagnostic test for the detection of HBV DNA sequences in serum at the single molecule level. Molec. cell. Probes 3: 45-57

Leong, J. C., Hsu, Y L., Engelking, H. M., Mulcahy, D. (1981). Strains of infectious hematopoietic necrosis (IHN) virus may be identified by structural protein differences. Dev. biol. Stand 49: 43-55

McAllister, P. E., Schill, W B. (1986). Immunoblot assay- A rapid and sensitive method for identification of salmonid fish viruses. J. wildl. Dis. 22: 468-474

Melchers, W. J. G., Schrift, R., Stolz, E., Lindeman, J., Quint, W. G. V (1989). Human papilloma virus detection in urine samples from male patients by the polymerase cham reaction. J. clin. Microbiol. 27: 1711-1714

Ou, Y. C., Kwok, S., Mitchell, S. W., Mack, D. H., Sninsky, J. J., Krebs, J. W., Feorino, P., Warfield, D., Schochetman, G. (1988). DNA amplification for direct detection of HIV-1 in DNA of peripheral blood mononuclear cells. Science 239: 295-297

Pilcher, K. S., Fryer, J. L. (1980). The viral diseases of fish: a review through 1978. CRC critical Rev. Microbiol. 7: $287-364$

Saiki, R. K., Scharf, S., Faloona, F., Mullis, K. B., Horn, G. T., Erlich, H. A., Arnheim, N. (1985). Enzymatic amplification of $\beta$-globin genomic sequences and restriction site analyses for diagnosis of sickle cell anemia. Science 230 : $1350-1354$

Saiki, R. K., Gelfand, D. H., Stoffel, S., Scharf, S. J., Higuchi, R., Horn, G. T., Mullis, K. B., Erlich, H. A. (1988). Primerdirected enzymatic amplification of DNA with a thermostable DNA polymerase. Science 239: 487-491 
Sano, T (1976). Viral diseases of cultured fishes in Japan. Fish Pathol. 10: 221-226

Steinhauer, D. A., De la Torre, J. C., Meier, E., Holland, J. J. (1989). Extreme heterogeneity in populations of vesicular stomatitis virus. J. Virology 63: 2072-2080

Responsible Subject Editor: Dr T Evelyn, Nanaimo, B.C., Canada
Way, K., Dixon, P. F. (1988). Rapid detection of VHS and IHN viruses by the enzyme-linked immunosorbent assay (ELISA). J. appl. Ichthy̆ol. 4: 182-189

Wolf, K. (1988). Fish viruses and fish viral diseases. Cornell University, Ithaca, New York

Manuscript first received: November 20, 1989

Revised version accepted: April 3, 1990 